\title{
Symmetric Compound Parabolic Concentrator with Indium Tin Oxide Coated Glass as Passive Cooling System for Photovoltaic Application
}

\author{
Damasen Ikwaba Paul \\ Physical Sciences Department, Faculty of Science, Technology and Environmental Studies, The Open University of Tanzania, \\ P.O. Box 23409, Dar es Salaam, Tanzania
}

Correspondence should be addressed to Damasen Ikwaba Paul; paul.ikwaba@out.ac.tz

Received 5 November 2015; Revised 24 January 2016; Accepted 3 February 2016

Academic Editor: Sundaram Senthilarasu

Copyright (C) 2016 Damasen Ikwaba Paul. This is an open access article distributed under the Creative Commons Attribution License, which permits unrestricted use, distribution, and reproduction in any medium, provided the original work is properly cited.

\begin{abstract}
One problem with concentrating photovoltaic systems is the increase in operating photovoltaic module temperature which results in power output reduction. Indium Tin Oxide (ITO) coated glasses exhibit both high transmittance in the visible region and high reflectance in the infrared region of the solar spectrum. Such materials can be used as selective windows in photovoltaic modules operating under concentrating system enabling passive cooling. In this paper, a Heat Reflector Window (HRW) consisting of a glass coated with $180 \mathrm{~nm}$ layer of ITO was experimentally tested. The ITO coated glass had a transmittance of about $85 \%$ in the visible region and over $80 \%$ reflectance in the infrared region of the solar spectrum and was placed at the exit aperture of a Compound Parabolic Concentrator (CPC). Results indicate that the temperature of a photovoltaic module under CPC with the HRW was reduced by about $50 \%$ as compared to a similar photovoltaic module with CPC but without the HRW. However, due to presence of the HRW at the exit aperture of the CPC, the photovoltaic module with the CPC and HRW received less solar irradiance compared to a similar photovoltaic module with the CPC but without HRW.
\end{abstract}

\section{Introduction}

The use of concentrating systems has been proposed as a way to reduce the cost of photovoltaic (PV) electrical energy generation and to enhance PV conversion efficiency [1]. The importance of cost reduction in PV concentrators originates from the fact that the optical element of the concentrating system is cheaper than purchasing additional PV modules thus leading to potential saving. However, one problem with the use of solar concentrating systems such as Compound Parabolic Concentrator (CPC) in PV application is the increase in operating PV module temperature which results in power output reduction [1-3]. In addition, long-time high operating PV module temperature causes irreversible PV module degradation which results in decrease in performance and PV module's lifetime [4]. Degradation of the PV module occurs when the front-side lamination is damaged, due to extended high temperature, causing optical decoupling of materials that transmit sunlight to the surface of the PV module and hence a gradual decrease in PV module performance.

Therefore, it is essential to avoid long-time extensive (e.g., beyond about $50^{\circ} \mathrm{C}$ ) heating of the PV modules under a concentrating system. The cooling of the PV module under a concentrating system can be achieved by either passive cooling methods [5-8] or active cooling methods $[6,9,10]$. Although most active cooling methods are more effective than existing passive cooling systems, they require supply of external energy. In addition, active cooling systems are usually more expensive and require more effort to maintain them. Furthermore, if the heat collector of the active cooling system has some problems, the PV module components may be damaged due to high temperature. For these reasons, passive cooling methods are usually preferred [11].

One typical report on passive system was a study of an infrared absorbing CPC shown in Figure 1 [8]. As shown 


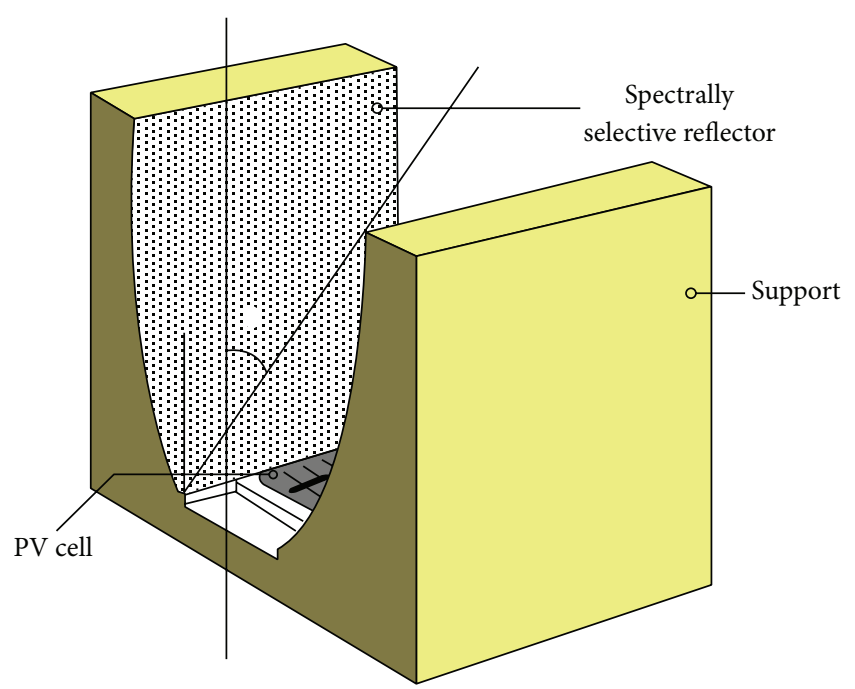

FIGURE 1: Integration of a spectrally selective reflector surface on a PV concentrator [8].

in Figure 1, the concentrating system in this experiment employed an infrared absorber on the reflecting surfaces of the CPC to absorb heat from the incident solar irradiance, thereby avoiding heat being reflected to the PV module. It is worth noting, however, that as the infrared absorber is exposed to sunlight for extended period, it will eventually be heated up to substantially high temperatures. As a consequence, it is likely that the absorber material will deteriorate. Indeed, Barrera et al. [12] have reported that infrared absorbers are chemically unstable under high temperatures. Since the wavelengths of the visible and infrared radiation do not overlap [13], instead of constructing a CPC with spectrally selective reflectors to absorb the infrared influx, it is possible to construct heat reflector material that selectively allows visible light through but reflects off the infrared portion of the solar spectrum.

Over the past four decades, several selective heat reflector materials have been investigated. These include Zinc Sulfide [14] and certain oxide semiconductors such as Zinc Oxide [15], Tin Oxide [14], Titanium Oxide [16], Boron Oxide [14], Indium Oxide [14], and Tin doped Indium Oxide frequently known as Indium Tin Oxide (ITO) [17, 18]. Among these selective heat reflector materials, ITO is reported to be the most suitable material for the fabrication of heat reflectors $[17,18]$.

Indium Tin Oxide is an n-type semiconductor with a band gap between 3.5 and $4.3 \mathrm{eV}$ and a maximum charge carrier concentration in the order of $10^{21} \mathrm{~cm}^{-3}$ [18]. Due to its high optical transmittance in the visible and nearinfrared light [18-22] as well as high reflectance [18] in the infrared spectral region, ITO is frequently used in photovoltaic devices [18-23] and various optoelectronic devices [19], infrared reflectors $[18,23]$, and flat panel display [18, 23]. Indium Tin Oxide has also been used as transparent electrodes for spectroelectrochemical studies due to its low electrical resistivity and its wide electrochemical window [24]. However, ITO properties are strongly dependent on the growth conditions such as ratio of oxygen, partial pressure, bias voltage, substrate temperature, growing rate, and postannealing [24]. The effect of growth technique on thin film growth is of considerable significance as films grown by two different techniques using the same precursor materials usually have different properties. This is attributed to the fact that the properties of the films depends, to a great extent, on their structure, microstructure, and the type of impurities present [25].

In the literature, there are various deposition techniques that have been used to grow ITO films which includes chemical vapour deposition [19], reactive plating [26], electron beam evaporation $[19,20]$, pulsed laser deposition [27], spray pyrolysis [18, 19], sol-gel [19, 28], thermal deposition [22], DC magnetron sputtering [19, 21, 24], and radio frequency (rf) magnetron sputtering [19, 30-32]. However, each of the ITO films deposition techniques has its own advantages and disadvantages. Table 1 shows the variations in transmittance and resistivity that have been observed when ITO films are prepared by different techniques.

In addition to high transmittance in the visible range (as shown in Table 1) and high reflectance in the infrared spectral region, ITO is thermally stable at less than $100^{\circ} \mathrm{C}$ [29] suggesting that there is no significant degradation of its optical properties when exposed to high temperature for long time.

Therefore, this paper investigated a passive cooling system consisting of ITO coated glass (here referred to as "Heat Reflector Window", HRW) placed at the exit aperture of a symmetric 2D CPC. The HRW reflects away the infrared influx portion of the solar spectrum instead of absorbing it, thus avoiding heat on the surface of a PV module placed underneath.

\section{Materials and Methodology}

2.1. Design and Fabrication of the Symmetric 2D CPC. For low latitude locations such as Dar es Salaam, Tanzania $\left(6^{\circ}\right.$ $\left.51^{\prime} \mathrm{S}, 39^{\circ} 18^{\prime} \mathrm{E}\right)$, low-concentrating symmetric $2 \mathrm{D} \mathrm{CPC}$ is capable of collecting significant solar irradiance without a tracking device. Thus, a standard symmetric 2D CPC, shown in Figure 2, was designed and fabricated for this study. The constructions of the CPC profiles for this study were based on the previously reported design $[1,2]$. The CPC had an acceptance half-angle $\left(\theta_{a}\right)$ and entrance $\left(A_{a}\right)$ and exit $\left(A_{r}\right)$ apertures areas of $18^{\circ}, 214 \mathrm{~mm}$, and $66 \mathrm{~mm}$, respectively, making a geometric concentration ratio $\left(C_{g}\right)$ of 3.24 . The CPC was truncated to a height of about $400 \mathrm{~mm}$ to enhance diffuse radiation collection and fabrication materials cost reduction [36]. Due to $\mathrm{CPC}$ end loss effect, the length of the fabricated CPC was made to be $300 \mathrm{~mm}$. Aluminium reflector sheet of thickness $0.5 \mathrm{~mm}$ (excluding the protective layer) was used as a reflector material because of its high reflectivity $\left(\mathrm{Al}_{\rho}=0.85\right)$, low cost, and good durability [1].

\subsection{Properties of the Heat Reflector Window (HRW) Glass.} The HRW used in this study constituted a glass coated with thin layer of ITO that was purchased from Praezisions Glas and Optik, GmbH, Germany. Table 2 lists the physical 
TABLE 1: Comparison of transmittance of ITO films prepared by different methods.

\begin{tabular}{|c|c|c|c|c|c|}
\hline Film deposition technique & Thickness (nm) & $\begin{array}{c}\text { Substrate } \\
\text { temperature }\left({ }^{\circ} \mathrm{C}\right)\end{array}$ & Resistivity $(\Omega \mathrm{cm})$ & $\begin{array}{c}\text { Transmittance } \\
(\%) \\
\end{array}$ & Reference \\
\hline Chemical vapour deposition & - & $350-450$ & $1.5-1.8 \times 10^{-4}$ & $90-95$ (visible) & [19] \\
\hline DC magnetron sputter & - & $\mathrm{RT}$ & $1.0 \times 10^{-3}$ & 85 (visible) & {$[21]$} \\
\hline DC magnetron sputter & 282 & RT & $5.4 \times 10^{-4}$ & $94(560 \mathrm{~nm})$ & {$[24]$} \\
\hline DC magnetron sputter & - & RT-453 & $1.2-160.0 \times 10^{-4}$ & 70-90 (visible) & {$[19]$} \\
\hline Electron beam evaporation & - & RT-440 & $0.7-12.0 \times 10^{-4}$ & 80-90 (visible) & [19] \\
\hline Electron beam evaporation & 150 & 350 & $3.0 \times 10^{-4}$ & 92 (visible) & {$[20]$} \\
\hline Ion and electron beam evaporation & 120 & $\mathrm{RT}$ & $5.1 \times 10^{-4}$ & $90(550 \mathrm{~nm})$ & [26] \\
\hline Pulsed laser deposition & - & RT & $4.0 \times 10^{-4}$ & $90(750 \mathrm{~nm})$ & {$[27]$} \\
\hline Reactive evaporation & - & 200 & $7.4 \times 10^{-4}$ & 90 (visible) & {$[26]$} \\
\hline RF magnetron sputter & 1400 & 380 & $6.3 \times 10^{-5}$ & 89 (visible) & {$[30]$} \\
\hline RF magnetron sputter & 900 & 400 & $3.7 \times 10^{-4}$ & 87 (visible) & {$[31]$} \\
\hline RF magnetron sputter & 40 & RT & $1.9 \times 10^{-2}$ & 92 (visible) & {$[32]$} \\
\hline RF magnetron sputter & & RT-450 & $1.7-7.0 \times 10^{-4}$ & 85-90 (visible) & [19] \\
\hline Sol-gel & 250 & 260 & $9.5 \times 10^{-4}$ & $90(900 \mathrm{~nm})$ & {$[28]$} \\
\hline Sol-gel & - & 500 & $4.2-100.0 \times 10^{-4}$ & 90 (visible) & [19] \\
\hline Spray pyrolysis & $200-900$ & $350-500$ & $5.0 \times 10^{-3}$ & 85-90 (visible) & {$[18]$} \\
\hline Spray pyrolysis & - & $420-677$ & $1.8-160.0 \times 10^{-4}$ & 82-92 (visible) & [19] \\
\hline Thermal deposition & 120 & 80 & $9.1 \times 10^{-4}$ & 80 (visible) & {$[22]$} \\
\hline
\end{tabular}

Note: RT means room temperature.

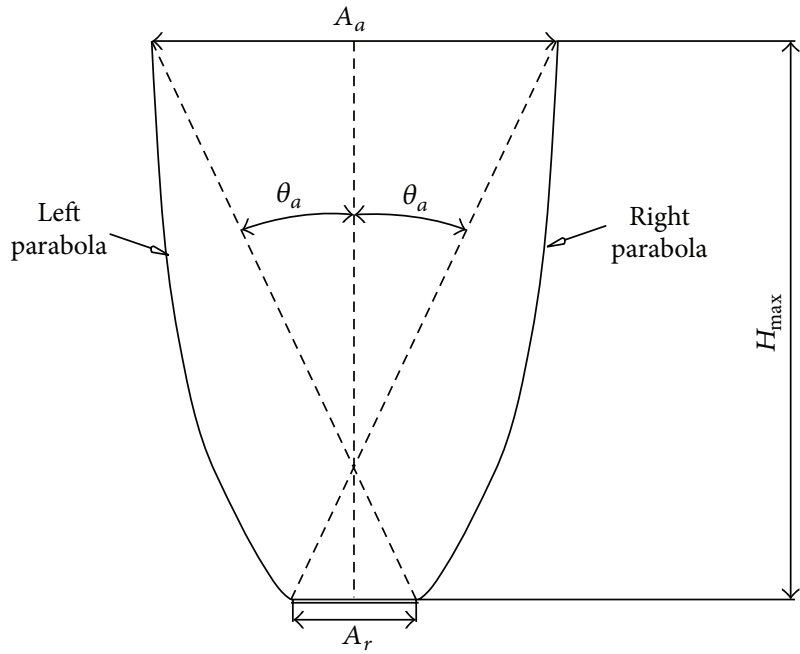

FIgure 2: Cross section view of a 2D symmetric CPC showing designing parameters. $H_{\max }$ is the maximum height of the CPC.
TABLE 2: Physical characteristics and optical properties of the ITO coated glass that was used in this study [33].

\begin{tabular}{|c|c|}
\hline \multicolumn{2}{|c|}{ Physical characteristics } \\
\hline Deposition technique & $\begin{array}{l}\text { Radio-frequency } \\
\text { magnetron sputtering }\end{array}$ \\
\hline & Single side ITO coating \\
\hline Coating construction & $\begin{array}{l}\mathrm{SiO}_{2} \text { passivation layer } \\
\text { between ITO layer and } \\
\text { glass substrate }\end{array}$ \\
\hline Type of substrate & $\begin{array}{l}\text { Polished high quality float } \\
\text { glass substrate }\end{array}$ \\
\hline Glass thickness & $2.5 \mathrm{~mm}$ \\
\hline ITO layer thickness & $180 \mathrm{~nm}$ \\
\hline $\begin{array}{l}\text { Dimensions (length and } \\
\text { width) }\end{array}$ & $300 \mathrm{~mm} \times 200 \mathrm{~mm}$ \\
\hline \multicolumn{2}{|c|}{ Optical properties } \\
\hline \multicolumn{2}{|c|}{ Electrically conductive and optically transparent } \\
\hline \multicolumn{2}{|c|}{ High visible light transmission $(>85 \%)$} \\
\hline \multicolumn{2}{|c|}{ High reflecting in the infrared range $(>80 \%)$} \\
\hline \multicolumn{2}{|c|}{ Uniform transmission homogeneity } \\
\hline
\end{tabular}

away the part of the solar spectrum which is responsible for heating up of a PV module.

Since the ITO coated glass has to be placed at the exit aperture of a 2D CPC with exit width of $66 \mathrm{~mm}$ and receiver (PV module) length of $124 \mathrm{~mm}$, the ITO coated glass was cut into a rectangular shape with dimensions of $130 \mathrm{~mm} \times 68 \mathrm{~mm}$. This piece of ITO coated glass was 
TABLE 3: Electrical characteristics of the PV modules at $1000 \mathrm{Wm}^{-2}$ solar irradiance [34].

\begin{tabular}{lccccc}
\hline Parameter & $\begin{array}{c}I_{\mathrm{SC}}{ }^{1} \\
(\mathrm{~mA})\end{array}$ & $\begin{array}{c}V_{\mathrm{OC}}{ }^{2} \\
(\mathrm{~V})\end{array}$ & $\begin{array}{c}I_{\mathrm{mpp}}{ }^{3} \\
(\mathrm{~mA})\end{array}$ & $\begin{array}{c}V_{\mathrm{mpp}}{ }^{4} \\
(\mathrm{~V})\end{array}$ & $\begin{array}{l}P_{\mathrm{mpp}}{ }^{5} \\
(\mathrm{~mW})\end{array}$ \\
\hline Value & 162.80 & 4.33 & 150.18 & 2.50 & 375.45 \\
\hline
\end{tabular}

${ }^{1}$ Short-circuit current.

${ }^{2}$ Open-circuit voltage.

${ }^{3}$ Current at maximum power point.

${ }^{4}$ Voltage at maximum power point.

${ }^{5}$ Power output at maximum power point.

positioned $3.5 \mathrm{~mm}$ above the PV module as illustrated in Figure 3(c).

2.3. Experimental Test Procedure. The main objective of this study was to examine the effectiveness of the proposed HRW cooling system by comparing the operating PV module temperature of three identical PV modules under different conditions. The PV modules used in this study were Polycrystalline Silicon manufactured by Shuang Li Electronic Co., Ltd., China. Table 3 shows the electrical properties of the PV module.

During the experimental testing, the PV modules were identified as follows:

(i) PV module-1: no accessories (i.e., without both CPC and HRW).

(ii) PV module-2: with symmetric CPC only.

(iii) PV module-3: with symmetric CPC and HRW (HRW is a cooling mechanism).

Figure 3 shows a schematic diagram of the experimental configuration.

The outdoor experimental testing shown in Figure 3 was carried out at the Physics Building, University of Dar es Salaam $\left(6^{\circ} 51^{\prime} \mathrm{S}, 39^{\circ} 18^{\prime} \mathrm{E}\right)$, Tanzania. The measurements were carried out repeatedly on cloudy and clear day over twenty days in the month of October. However, the data presented in this paper were for the best clear sky day.

For the purpose of evaluating the effectiveness of the proposed cooling system (HRW), two identical CPCs, one with HRW (Figure 3(c)) and the other without HRW (Figure 3(b)), were fabricated. The supportive-base for the CPC intended to be used with the HRW had a slot, $3.5 \mathrm{~mm}$ above the PV module, for inserting the HRW glass (Figure 3(c)). In order to have the same solar irradiance on the PV module without the CPC as that on the aperture of the CPC, a supportive wooden block (Figure 3(a)), with the same height as the height of the CPC, was fabricated. During experimental testing, this wooden block was used as a supportive base for PV module-1 as illustrated in Figure 3(a).

For each PV module, current and voltage were measured manually using a fixed resistive load method [37]. This method is achieved by incorporating a fixed resistive load in the circuit as shown in Figure 4. As this method does not automatically adjust the load to ensure maximum power output as the solar irradiance varies throughout the day, the value of the optimal resistive load, $R_{\text {optimal }}$, for this experiment was determined as the ratio of the voltage at $P_{\mathrm{mpp}}$ $\left(V_{\text {mpp }}\right)$ to the current at $P_{\text {mpp }}\left(I_{\text {mpp }}\right)$ at standard temperature condition [37]. The determination of optimal resistive load is very important due to the fact that if the resistive load is smaller than $R_{\text {optimal }}$, the PV module behaves as a constant current source (almost equal to the short-circuit current, independent of the voltage) which in turn causes nonlinear relationship between irradiance and maximum output power and hence lower output power [37]. On the other hand, if the resistive load is much larger than $R_{\text {optimal }}$, the PV module behaves as a constant voltage source (practically equal to the open-circuit voltage) and therefore the output power is independent of the irradiance level $[37,38]$.

It is a well-known fact that the resistance of a material changes with temperature due to collisional processes within the material and it has been found that, at room temperature to about $100^{\circ} \mathrm{C}$, the resistance $\left(R_{T}\right)$ increases linearly with temperature according to the following [39]:

$$
R_{T}=R_{0}\left[1+\alpha\left(T-T_{0}\right)\right]
$$

where $\alpha$ is the temperature coefficient of resistivity, $R_{T}$ is the resistance of the material at temperature $T, T_{0}$ is the reference temperature (i.e., room temperature), and $R_{0}$ is the resistance at room temperature.

According to (1), the resistance of the optimal load $\left(R_{\text {optimal }}\right)$ in Figure 4 was expected to increase with temperature. However, the change in resistance due to small change in temperature is normally quite small [40]. This is because the manufacturer has chosen a material having a resistivity not greatly influenced by temperature. Therefore, the resistance of the optimal load used in this study was not subject to significant changes due small variations in ambient temperature for Dar es Salaam location (see Figure 7).

To minimize experimental error which could be introduced by the internal resistance of different digital ammeters and voltmeters, the current and voltage of each PV module were measured by using the same digital multimeter (Fluke 115 AC/DC digital multimeter). The Fluke 115 AC/DC digital multimeter is an upgraded version of Fluke 114 multimeter, with the ability to measure AC/DC current, AC/DC voltage, resistance, continuity, frequency, capacitance, and diode [35]. This digital multimeter can measure DC and AC voltage up to $600 \mathrm{~V}$, continuity up to $600 \Omega$, resistance up to $40 \mathrm{M} \Omega$, amps up to $10 \mathrm{~A}$, and frequency up to $50 \mathrm{kHz}$. Table 4 lists the technical and general specifications of the Fluke $115 \mathrm{AC} / \mathrm{DC}$ digital multimeter.

Since it was a clear sky day, the current and voltage of each PV module were recorded after every 10 -minute interval.

For measuring the ambient temperature and the rear surface temperature of each module, T-type thermocouples were used. The temperature of the PV modules was measured by attaching one thermocouple at the rear surface (at the centre) of each PV module while a cylindrical tube with a thermocouple for measuring ambient temperature was mounted vertically on the underside of an experimental test rig. The cylindrical tube had a white tape wrapped around it and holes around to shield the thermocouple against sunlight and to allow free air circulation, respectively. All the 


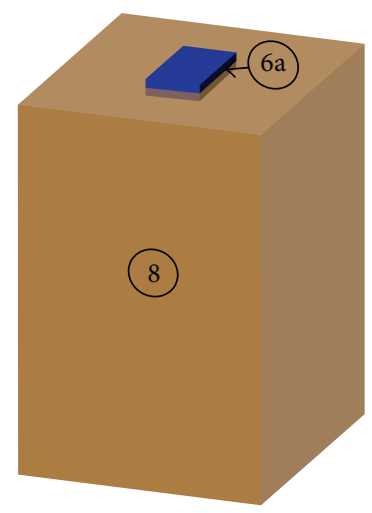

(a) Nonconcentrated system (PV module-1)

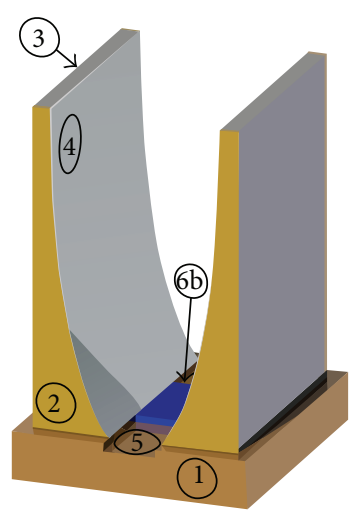

(b) PV module-2 + CPC

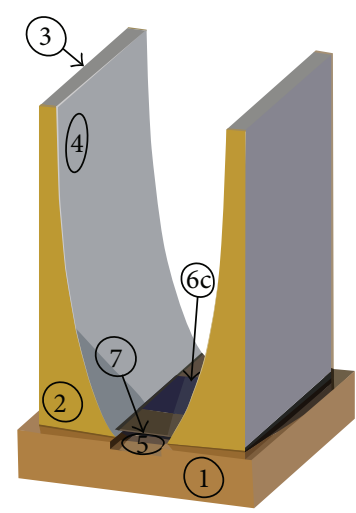

(c) PV module-3 + CPC + HRW

FIGURE 3: Layout of the three experimental test systems: (a) nonconcentrating system (PV module-1), (b) PV module-2 + CPC, and (c) PV module-3 + CPC + HRW. The numbers in this figure indicate (1) PV module and reflector supportive-base, (2) CPC enclosure system, (3) hard-wood flat bar, (4) aluminium reflector sheet, (5) wide-trough for inserting PV module, (6a) PV module-1, (6b) PV module-2, (6c) PV module-3, (7) ITO coated glass (note: ITO coated glass is transparent to visible light, hence not quite apparent in the figure, but it is just above the PV module), and (8) wooden block.

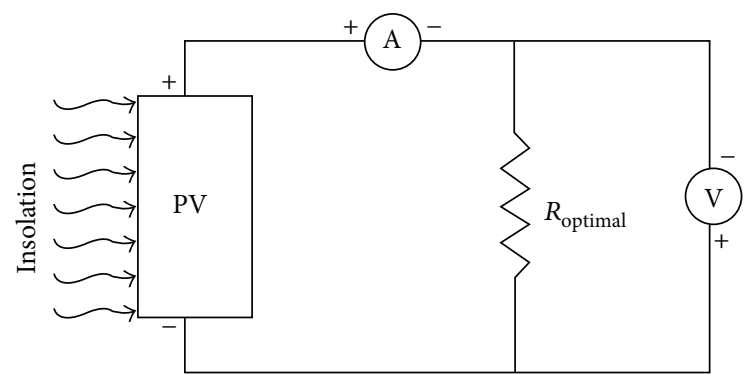

FIGURE 4: Standard circuit for PV module current and voltage measurement.

thermocouples were connected to a data logger which was programmed to take readings at every 1 minute and average the results after 10 minutes. Solar irradiance was measured by a Pyranometer.

\section{Results and Discussions}

\subsection{Optical Properties and Energy Flux Profiles along the PV Module for the CPC with and without HRW}

3.1.1. Angular Acceptance and Optical Efficiency. The performance of any PV module with a concentrator mainly depends on the optical efficiency of the collector and the energy flux distribution on the surface of the PV module [1]. The former is the ratio of the energy absorbed by the $\mathrm{PV}$ module to the energy incident along the aperture of the concentrator [41] while the later shows the profile of the energy flux on the PV module [42]. The evaluation of optical efficiency of a concentrating system is an important process because it is a measure of the quality of the concentrating unit [42]. On the other hand, the way in which solar radiation is incident on the surface of a concentrated PV module is vital to its performance because different nonuniform energy flux profiles have different negative effect on the electrical performance of a PV module [2]. Therefore, the first task in this investigation was to compare the angular acceptance, optical efficiency, and energy flux profiles of the CPC with and without the HRW.

The angular acceptance (which is a fraction of rays incident on the collector aperture at an incidence angle, $\theta$, reaching the receiver $[42,43])$, optical efficiency, and energy flux profiles for the CPC with and without the HRW were analyzed using a ray-tracing simulation program developed by Zacharopoulos [44]. This program calculates (for each ray) the point of intersection and the associated angles of incidence and refraction on the surfaces of the reflector, HRW glass, and PV module. Note that with reference to solar energy systems, incidence angle is the angle that a ray of sun makes with a line perpendicular to the surface; for example, a surface that directly faces the sun has a solar angle of incidence of zero, but if the surface is parallel to the sun (e.g., sunrise striking a horizontal rooftop), the angle of incidence is $90^{\circ}$. The ray-tracing simulation program used in this study also calculates the energy absorbed and refracted by the reflector surfaces and the total energy absorbed by the HRW glass and PV module. Furthermore, the ray-tracing program calculates the energy flux distribution across the PV module as well as number of ray reflections on the reflector surfaces. The program computes all these values for a sufficient number of initial rays such that the averaged outcome of the rays is a fair representation of what happens in real situations.

For each angle of incidence examined, 10,000 rays equally spaced over the aperture of each system were traced (from the aperture of the CPC until they reached the PV module or exited through the aperture of the CPC after multiple reflections). In this simulation, the PV module was assumed to be a perfect absorber of solar irradiance [45] and the aluminium reflector surface was assumed to be specular [46] with a reflectivity equal to that used in the fabrication of the 
TABLE 4: Fluke 115 AC/DC digital multimeter technical and general specifications [35].

(a) Accuracy specifications

\begin{tabular}{|c|c|c|c|}
\hline Function & Range & Resolution & Accuracy $\pm([\%$ of reading $]+[$ counts $])$ \\
\hline Millivolts & $600.0 \mathrm{mV}$ & $0.1 \mathrm{mV}$ & $0.5 \%+2$ \\
\hline DC volts & $\begin{array}{l}6.000 \mathrm{~V} \\
60.00 \mathrm{~V} \\
600.0 \mathrm{~V}\end{array}$ & $\begin{array}{c}0.001 \mathrm{~V} \\
0.01 \mathrm{~V} \\
0.1 \mathrm{~V}\end{array}$ & $0.5 \%+2$ \\
\hline $\begin{array}{l}\text { AC millivolts } \\
\text { true-rms }\end{array}$ & $600.0 \mathrm{mV}$ & $0.1 \mathrm{mV}$ & $\begin{array}{l}45 \mathrm{~Hz} \text { to } 500 \mathrm{~Hz}: 1.0 \%+3 \\
500 \mathrm{~Hz} \text { to } 1 \mathrm{kHz}: 2.0 \%+3\end{array}$ \\
\hline $\begin{array}{l}\text { AC volts } \\
\text { true-rms }\end{array}$ & $\begin{array}{l}6.000 \mathrm{~V} \\
60.00 \mathrm{~V} \\
600.0 \mathrm{~V}\end{array}$ & $\begin{array}{c}0.001 \mathrm{~V} \\
0.01 \mathrm{~V} \\
0.1 \mathrm{~V} \\
\end{array}$ & $\begin{array}{l}45 \mathrm{~Hz} \text { to } 500 \mathrm{~Hz}: 1.0 \%+3 \\
500 \mathrm{~Hz} \text { to } 1 \mathrm{kHz}: 2.0 \%+3\end{array}$ \\
\hline Continuity & $600 \Omega$ & $1 \Omega$ & $\begin{array}{l}\text { Detects opens or shorts of } 500 \mu \mathrm{s} \text { or } \\
\text { longer }\end{array}$ \\
\hline Ohms & $\begin{array}{c}600.0 \Omega \\
6.000 \mathrm{k} \Omega \\
60.00 \mathrm{k} \Omega \\
600.0 \mathrm{k} \Omega \\
6.000 \mathrm{M} \Omega \\
40.00 \mathrm{M} \Omega \\
\end{array}$ & $\begin{array}{c}0.1 \Omega \\
0.001 \mathrm{k} \Omega \\
0.01 \mathrm{k} \Omega \\
0.1 \mathrm{k} \Omega \\
0.001 \mathrm{M} \Omega \\
0.01 \mathrm{M} \Omega \\
\end{array}$ & $\begin{array}{l}0.9 \%+2 \\
0.9 \%+1 \\
0.9 \%+1 \\
0.9 \%+1 \\
0.9 \%+1 \\
1.5 \%+2 \\
\end{array}$ \\
\hline Diode test & $2.000 \mathrm{~V}$ & $0.001 \mathrm{~V}$ & $0.9 \%+2$ \\
\hline Capacitance & $\begin{array}{l}1000 \mathrm{nF} \\
10.00 \mu \mathrm{F} \\
100.0 \mu \mathrm{F} \\
9999 \mu \mathrm{F} \\
\end{array}$ & $\begin{array}{c}1 \mathrm{nF} \\
0.01 \mu \mathrm{F} \\
0.1 \mu \mathrm{F} \\
1 \mu \mathrm{F}\end{array}$ & $\begin{array}{l}1.9 \%+2 \\
1.9 \%+2 \\
1.9 \%+2 \\
100 \mu \mathrm{F} \text { to } 1000 \mu \mathrm{F}: 1.9 \%+2 \\
>1000 \mu \mathrm{F}: 5 \%+20\end{array}$ \\
\hline AC amps $(45 \mathrm{~Hz}$ to $500 \mathrm{~Hz})$ & $\begin{array}{c}6.000 \mathrm{~A} \\
10.00 \mathrm{~A} \\
20 \mathrm{~A} \text { overload for } 30 \\
\text { seconds maximum }\end{array}$ & $\begin{array}{c}0.001 \mathrm{~A} \\
0.01 \mathrm{~A}\end{array}$ & $1.5 \%+3$ \\
\hline DC amps & $\begin{array}{c}6.000 \mathrm{~A} \\
10.00 \mathrm{~A} \\
20 \text { A overload for } 30 \\
\text { seconds maximum }\end{array}$ & $\begin{array}{c}0.001 \mathrm{~A} \\
0.01 \mathrm{~A}\end{array}$ & $1.0 \%+3$ \\
\hline $\mathrm{Hz}$ (V or A input) & $\begin{array}{c}99.99 \mathrm{~Hz} \\
999.9 \mathrm{~Hz} \\
9.999 \mathrm{kHz} \\
50.00 \mathrm{kHz} \\
\end{array}$ & $\begin{array}{c}0.01 \mathrm{~Hz} \\
0.1 \mathrm{~Hz} \\
0.001 \mathrm{kHz} \\
0.01 \mathrm{kHz} \\
\end{array}$ & $0.1 \%+2$ \\
\hline
\end{tabular}

(b) Frequency counter sensitivity

\begin{tabular}{lcccc}
\hline \multirow{2}{*}{ Input range } & \multicolumn{4}{c}{ Typical sensitivity (rms sine wave) } \\
& $5 \mathrm{~Hz}$ to $45 \mathrm{~Hz}$ & $45 \mathrm{~Hz}$ to $5 \mathrm{kHz}$ & $5 \mathrm{kHz}$ to $10 \mathrm{kHz}$ & $10 \mathrm{kHz}$ to $50 \mathrm{kH}$ \\
\hline \multirow{3}{*}{ Volts $\mathrm{AC}$} & $6 \mathrm{~V}$ & $0.2 \mathrm{~V}$ & $0.2 \mathrm{~V}$ to $0.3 \mathrm{~V}$ & $0.3 \mathrm{~V}$ to $0.4 \mathrm{~V}$ \\
& $60 \mathrm{~V}$ & $2 \mathrm{~V}$ & $2 \mathrm{~V}$ to $3 \mathrm{~V}$ & $3 \mathrm{~V}$ to $4 \mathrm{~V}$ \\
& $600 \mathrm{~V}$ & $20 \mathrm{~V}$ & $0 \mathrm{~V}$ to $30 \mathrm{~V}$ & $30 \mathrm{~V}$ to $40 \mathrm{~V}$ \\
\hline \multirow{2}{*}{ AC amps } & $6 \mathrm{~A}$ & \multirow{2}{*}{$\mathrm{N} / \mathrm{A}$} & $0.4 \mathrm{~A}$ & N/A \\
& $10 \mathrm{~A}$ & & $0.5 \mathrm{~A}$ & \\
\hline
\end{tabular}

(c) Input characteristics

\begin{tabular}{lccc}
\hline Function & Input impedance (nominal) & Common mode rejection ratio $(1 \mathrm{~kW}$ unbalanced) & Normal mode rejection \\
\hline Volt AC & $>5 \mathrm{M} \Omega<100 \mathrm{pF}$ & $>60 \mathrm{~dB}$ at dc, 50 or $60 \mathrm{~Hz}$ & - \\
\hline Volts DC & $>10 \mathrm{M} \Omega<100 \mathrm{pF}$ & $>100 \mathrm{~dB}$ at dc, 50 or $60 \mathrm{~Hz}$ & $>60 \mathrm{~dB}$ at 50 or $60 \mathrm{~Hz}$ \\
\hline Auto-V LoZ & $\sim 3 \mathrm{k} \Omega<500 \mathrm{pF}$ & $>60 \mathrm{~dB}$ at dc, 50 or $60 \mathrm{~Hz}$ & - \\
\hline
\end{tabular}


(c) Continued.

\begin{tabular}{lcccc}
\hline Function & Input impedance (nominal) & Common mode rejection ratio (1 kW unbalanced) & Normal mode rejection \\
\hline \multirow{2}{*}{ Ohms } & Open-circuit test voltage & \multicolumn{2}{c}{ Full scale voltage } & Short-circuit current \\
& $<2.7 \mathrm{~V} \mathrm{dc}$ & To $6.0 \mathrm{M} \Omega$ & To $6.0 \mathrm{M} \Omega$ & $<350 \mu \mathrm{A}$ \\
\hline Diode test & $2.7 \mathrm{~V} \mathrm{dc}$ & $<0.7 \mathrm{~V} \mathrm{dc}$ & $<0.9 \mathrm{~V} \mathrm{dc}$ & $<1.2 \mathrm{~mA}$ \\
\hline
\end{tabular}

(d) General specifications

\begin{tabular}{|c|c|}
\hline Function & Description \\
\hline $\begin{array}{l}\text { Maximum voltage between any } \\
\text { terminal and earth ground }\end{array}$ & $600 \mathrm{~V}$ \\
\hline Surge protection & $6 \mathrm{kV}$ peak per IEC 61010-1 600 V CAT III, Pollution Degree 2 \\
\hline W Fuse for A input & 11 A, 1000 V FAST 17 kA Fuse (Fluke PN 803293) \\
\hline Display & Digital: 6,000 counts, updates 4/sec; Bar Graph: 33 segments, updates 32/sec \\
\hline Temperature & Operating: $-10^{\circ} \mathrm{C}$ to $+50^{\circ} \mathrm{C}$; Storage: $-40^{\circ} \mathrm{C}$ to $+60^{\circ} \mathrm{C}$ \\
\hline Humidity & $\begin{array}{l}0 \% \text { to } 90 \% \text { to } 35^{\circ} \mathrm{C} \\
75 \% \text { to } 40^{\circ} \mathrm{C} \\
45 \% \text { to } 50^{\circ} \mathrm{C}\end{array}$ \\
\hline Temperature coefficient & $0.1 \times\left(\right.$ specified accuracy $\left./{ }^{\circ} \mathrm{C}\right)\left(<18^{\circ} \mathrm{C}\right.$ or $\left.>28^{\circ} \mathrm{C}\right)$ \\
\hline Operating altitude & 2,000 meters \\
\hline Battery & 9 Volt Alkaline, NEDA 1604 A/IEC 6LR61 \\
\hline Battery life & Alkaline: 400 hours typical, without backlight \\
\hline Safety compliances & $\begin{array}{l}\text { ANSI/ISA 82.02.01 (61010-1) 2004, CAN/CSA C22.2 No 61010-1-04, UL 6101B } \\
\text { (2003) and IEC/EN 61010-1 2nd Edition for measurement Category III, } 600 \text { V, } \\
\text { Pollution Degree 2, EMC EN61326-1 }\end{array}$ \\
\hline Certifications & UL, CSA, TUV, N10140, VDE \\
\hline Model & Fluke 115 \\
\hline Manufacturer & Fluke Corporation, USA \\
\hline
\end{tabular}

reflector profiles of the CPC. For the case of the HRW, its absorptance in the visible portion of the solar spectrum was taken as 0.85 . Figure 5 shows the angular acceptance and optical efficiency of the CPC with and without HRW as a function of incidence angles. It can be seen that both units (CPC with and without HRW) have an equal angular acceptance of $100 \%$ within their acceptance angle limits. Furthermore, for each incidence angle, both systems (CPC with and without HRW) have the same angular acceptance because both systems were fabricated using the same reflector material and have similar reflecting surface geometries. It should be noted that, for any concentrating system, the angular acceptance depends on the properties (i.e., reflectivity, absorptance, extinction coefficient, and thickness) of the aperture cover material (if any), the reflectivity of the reflector, and reflector surface geometry [1]. The analysis of the angular acceptance presented in Figure 5 leads to the conclusion that any difference in terms of temperature or electrical performance that will be observed between PV module-2 (the PV module with the CPC but without the HRW) and PV module-3 (the PV module with the CPC and HRW) will not be a result of having different angular acceptance.

Since the optical efficiency of the CPC takes into consideration of the absorption property of the receiver, it can be seen from Figure 5 that, between $-15^{\circ}$ and $+15^{\circ}$ incidence angle, the optical efficiency of the CPC with the HRW was

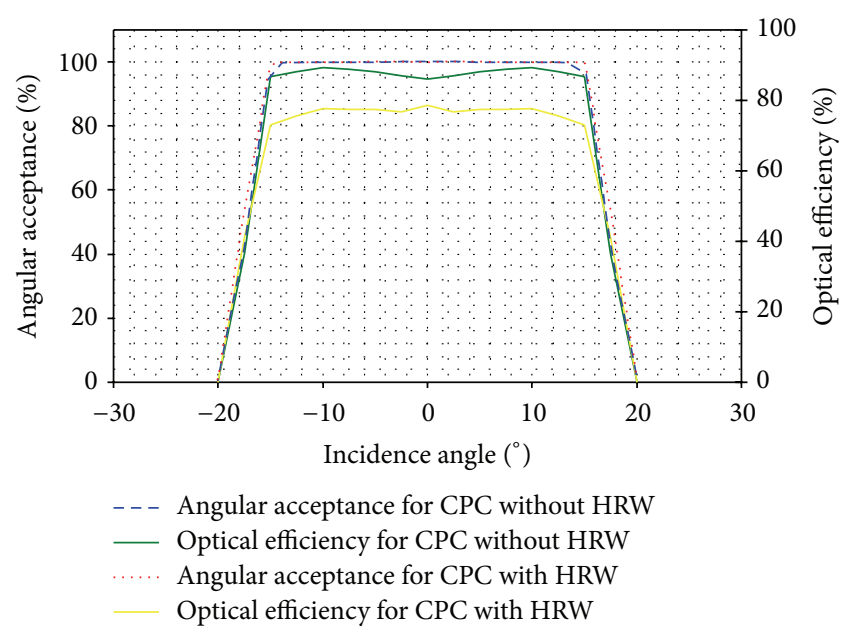

FIGURE 5: Variation in angular acceptance and optical efficiency of symmetric CPC with and without the HRW for different solar incidence angles.

about $15 \%$ less than that without the HRW. The observed discrepancy was due to the fact that when solar irradiance strikes the surface of the HRW, a fraction of the energy is absorbed within the HRW and some is transmitted through 

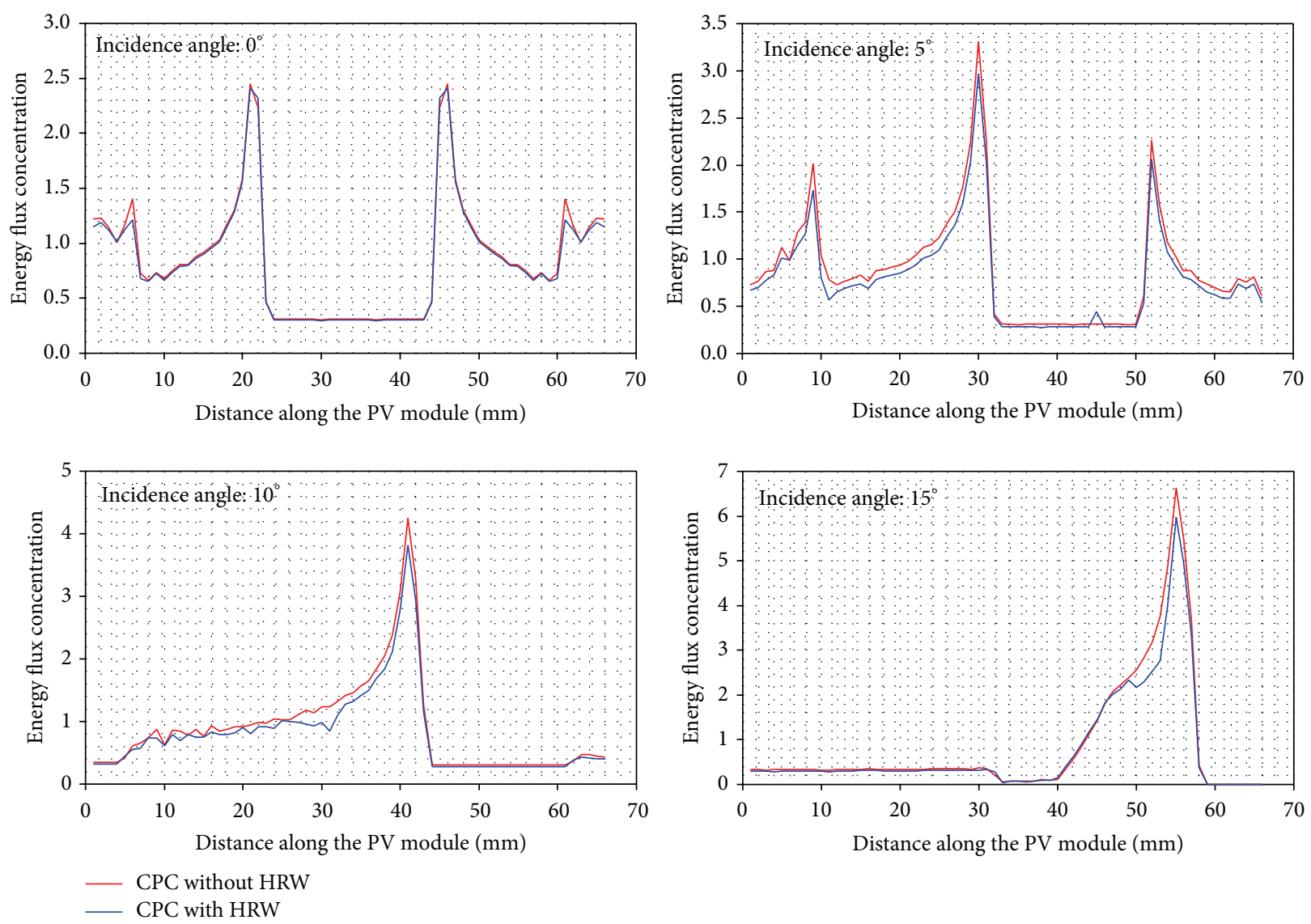

Figure 6: Simulated solar energy flux distribution along the PV module for the CPC with and without $\mathrm{HRW}$ for $0^{\circ}, 5^{\circ}, 10^{\circ}$, and $15^{\circ}$ incidence angle of solar irradiance.

to the PV module. On the other hand, for the incidence angles near or above the acceptance angle limit of the CPC (i.e., between $-15^{\circ}$ and $-20^{\circ}$ and between $+15^{\circ}$ and $+20^{\circ}$ ), both systems have the same optical efficiency. This leads to the conclusion that, in general, the PV module with the CPC and HRW (PV module-3) receives less solar energy compared to the PV module with the CPC but without HRW (PV module2). Thus, from purely optical efficiency point of view, the current and power output produced by PV module- 3 will be less than that of PV module-2 due to the fact that current and power output of a PV module are direct proportional to the absorbed solar energy flux (assuming that the operating PV module temperature does not increase beyond ambient temperature).

3.1.2. Energy Flux Distribution along the PV Module. Figure 6 shows the simulated solar energy flux distribution along the $\mathrm{PV}$ module for the CPC with and without HRW for $0^{\circ}, 5^{\circ}$, $10^{\circ}$, and $15^{\circ}$ incidence angle of solar radiation. It can be seen that, for the incidence angles examined, the profiles of energy flux distribution along the PV module for the CPC with and without HRW are in a very good agreement. This indicates that the positions at which the solar rays hit the PV module with HRW and a similar PV module but without HRW were the same. This observation was due to the fact that the HRW did not alter the directions of the rays as they travel within the HRW. As illustrated in Figure 6, the most significant difference between the PV module with the CPC but without HRW and the PV module with the CPC + HRW is apparent in the energy flux concentration (i.e., the average solar energy flux on the surface of the PV module [47]), especially above normal (i.e., $0^{\circ}$ ) incidence angle. It can be seen that when the comparison of the energy flux concentration is based on each point along the PV module, the magnitude of the energy flux concentration for the PV module without HRW is always higher than that of the PV module with HRW. The difference varies with the position along the PV module and angle of incidence. This variation increases with the increase in incidence angle because as the incidence angle increases, more abortion takes place in the HRW since rays have to travel long distance in the HRW and hence less energy is transmitted to the surface of the PV module.

Since the current (and power output) generated by a $\mathrm{PV}$ module is based on the total energy flux concentration on the whole area of a PV module rather than on energy flux concentration at each point along the PV module, a comparison of the energy flux concentration based on the sum of the energy flux on the entire PV module was made and is shown in Table 5. It can be seen that, for all incidence angle examined, the total energy flux concentration on the 
TABLE 5: Variation in total energy flux concentration on the entire PV module with and with HRW as function of incidence angle.

\begin{tabular}{lcr}
\hline Incidence angle $\left(^{\circ}\right)$ & \multicolumn{2}{c}{$\begin{array}{c}\text { Sum of all energy flux concentration for the entire PV module area } \\
\text { PV module with the CPC and HRW }\end{array}$} \\
\hline $\mathbf{0}$ & PV module with the CPC but without HRW & 55.61 \\
$\mathbf{5}$ & 56.84 & 52.54 \\
$\mathbf{1 0}$ & 58.26 & 53.12 \\
$\mathbf{1 5}$ & 59.16 & 51.62 \\
\hline
\end{tabular}

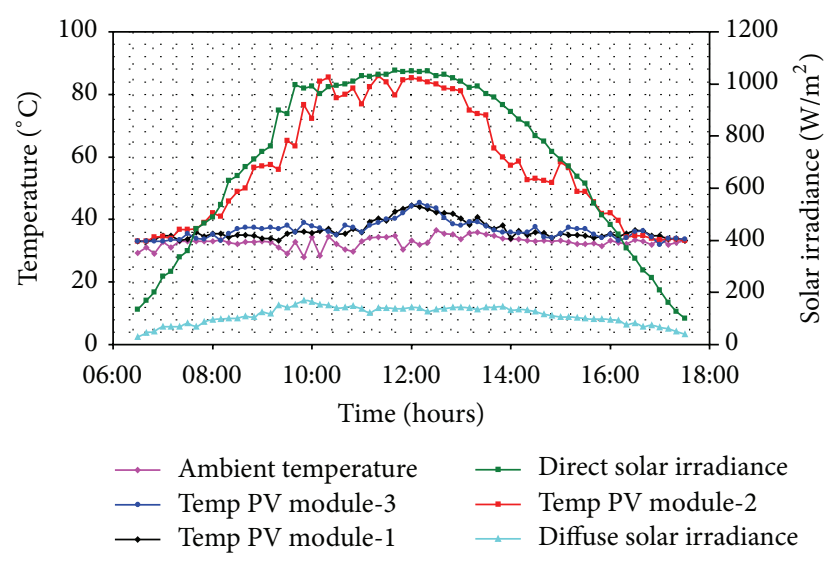

FIgURE 7: Diurnal variations in temperature for the three PV modules on a clear sunny day, including the variations of solar irradiance throughout the experimental test period.

entire PV module for the test unit without HRW was always higher than that of the PV module with HRW. The variation increases with increase in incidence angles due to high reflection of visible light by the HRW glass that was used in this study. From this analysis, it can be concluded that, due to HRW at the exit aperture of the CPC, the current and power output for the PV module without HRW will be greater than that of the PV module with the CPC but without HRW.

\subsection{Experimental Results}

3.2.1. Operating PV Module Temperatures. Figure 7 shows the variations of total and diffuse solar irradiance on the aperture of the CPCs and the PV module without the CPC collector as well as the hourly variations of the back-surface temperature for the three PV modules. It can be seen that, throughout the experimental test period, the direct solar irradiance was high, indicating a clear sky day. As can be observed from Figure 7, the maximum direct solar irradiance was about $1000 \mathrm{~W} / \mathrm{m}^{2}$ (around solar noon) and, due to high degree of the atmospheric transparency, the diffuse solar irradiance remained below $160 \mathrm{~W} / \mathrm{m}^{2}$ for most of the time of the experimental testing.

Due to the increase in the energy flux as a result of using concentrating system (the CPC), it can be seen that the operating temperature for PV module-2 (PV module with the CPC but without HRW) was higher than the operating temperature for PV module-1 (PV module without concentrating system). This difference varies with time of the day due to variations of energy flux received by the two PV modules as the incidence angle changes with the sun's movement across the sky. For example, at low incidence angles (e.g., at 0800 and 1600 hours), the operating temperature for PV module- 2 was higher than PV module-1 by about $6^{\circ} \mathrm{C}$ while at solar noon; the operating temperature for PV module-2 was higher than PV module- 1 by about $41^{\circ} \mathrm{C}$. The low operating temperatures observed at low incidence angles for PV module-2 were due to the fact that at low incidence angles the sun is at the horizon and the sunrays' incidence angle was situated, to a greater extent, outside the designing acceptance angle of the symmetric CPC.

As illustrated in Figure 7, it can be seen that, throughout the experimental testing periods, there was no substantial variation in operating temperature for the PV module with the CPC and cooling system (HRW) (i.e., PV module-3) and the PV without the CPC (i.e., PV module-1). This is because the operating temperature of PV module- 3 was kept low by the cooling system (the HRW glass) which was placed at the exit aperture of the CPC. Thus, a portion of the solar spectrum (infrared) responsible for the increase in operating temperature of the PV module was reflected off before reaching the surface of the PV module. From this observation, it can be concluded that a glass of $2.5 \mathrm{~mm}$ thick coated with $180 \mathrm{~nm}$ layer of ITO is capable of keeping the operating temperature of the PV module under the CPC to the same value as that without the CPC collector. However, when comparison of the operating temperature is made between the PV modules with a concentrating system, it can be seen from Figure 7 that although both PV module- 2 and module-3 use identical concentrating system (CPC), the temperature for PV module-2 was always higher than that of PV module-3. This difference varies with time of the day due to variations of solar irradiance as the incidence angle changes with the sun's movement across the sky. For example, at low incidence angles (e.g., before 0800 and after 1600 hours), both PV modules had low and nearly the same operating temperatures. This can be explained by little amount of solar energy flux received by each PV module as a result of CPC's designing acceptance angle restriction. Nevertheless, at solar noon, despite both PV modules receiving maximum solar irradiance, the temperature for PV module-3 did not increase beyond $45^{\circ} \mathrm{C}$ due to the cooling system (HRW) placed at the exit aperture of the CPC whereas that of PV module- 2 was as high as $85^{\circ} \mathrm{C}$. This means that the infrared influx responsible for the rise in operating temperature was reflected off by the HRW glass before reaching PV module-3. From this analysis, 


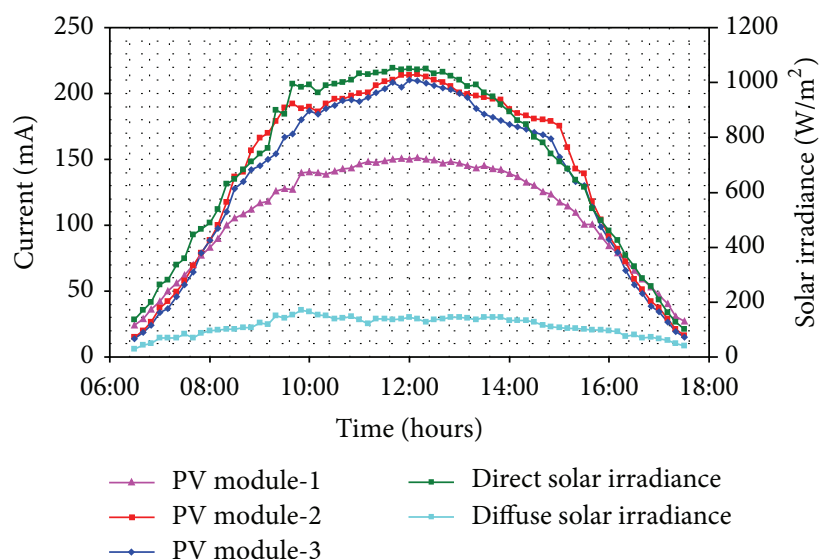

(a)

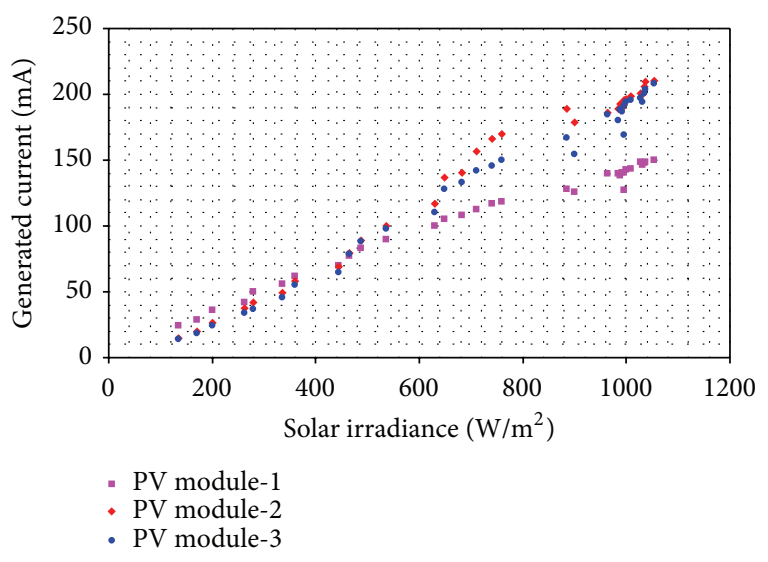

(b)

FIGURE 8: (a) Variation in current output of the three PV modules at different time of the test period. The corresponding solar irradiance is also shown. (b) Variation in current output of the three PV modules as function of solar irradiance.

it can be concluded that the temperature of the PV module under a CPC system can be kept low by the use of HRW as much as two orders of magnitude compared to one placed under the CPC without HRW.

3.2.2. Variation in Current Output. The variations in the current output of the three PV modules are shown in Figure 8. It is clearly observed in Figure 8(a) that the currents of the three PV modules are symmetrical with respect to noon. For example, the current for PV module-1, PV module-2, and PV module-3 increased from about $62 \mathrm{~mA}, 58 \mathrm{~mA}$, and $55 \mathrm{~mA}$ at 0730 hour to maximum at midday and then fall again to about $66 \mathrm{~mA}, 59 \mathrm{~mA}$, and $55 \mathrm{~mA}$ at 1630 hour, respectively. As expected, this symmetrical behaviour of currents is the mirror of the solar irradiance received by each PV module. On the other hand, it can be observed in Figure 8(a) that, during the early hours of the day (i.e., before 0800 hour) and late afternoon (after 1600 hour), the PV module without concentrating system generated more current than the other two PV modules with the CPC. This is explained by the fact that the CPC does not effectively collect sunlight during the early hours of the day or just before sundown because the incidence angle of the sunrays is situated outside the designing acceptance angle of the symmetric CPC.

As indicated in Figure 8(a), PV module-2 generated more current than PV module-3 despite the fact that both modules had the same concentrating mechanism (the CPC). The difference in current for these PV modules is more clearly shown in Figure 8(b), which is the dependence of PV module current on solar irradiance. Analysis of the slopes of current in Figure 8(b) shows that the average slope $\left(\Delta I / \Delta S_{\text {irr }}\right)$ for PV module-1, PV module-2, and PV module-3 is $0.128,0.204$, and $0.192 \mathrm{~mA} / \mathrm{Wm}^{-2}$, respectively. This also indicates that PV module-2 generated more current than other two similar PV modules. This is due to the fact that the glass coated with ITO, which was used to construct the HRW, had substantial amount of reflectance of visible light. This was shown in optical efficiency analysis (Figure 5) which indicated that,

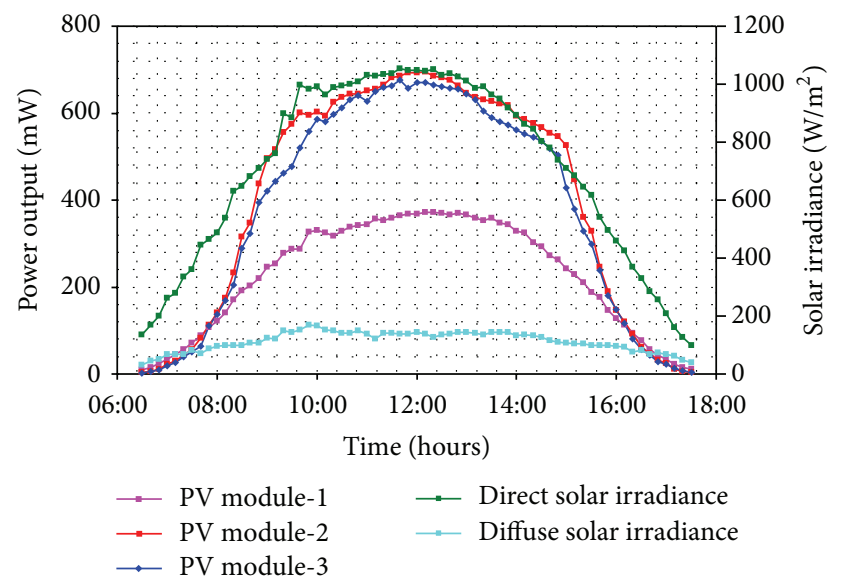

FIgURE 9: Comparison of power output of the three PV modules over the test period. The corresponding solar irradiance is also shown.

owing to HRW, the optical efficiency of the CPC with the HRW was about $15 \%$ less than that without the HRW. As the result, the total energy flux incident on PV module-2 was higher than that of PV module-3 (Figure 6). This means that PV module- 3 received relatively less amount of visible light (which is responsible for generation of current) than the amount received by PV module- 2 .

3.2.3. Variation in Power Output. The comparison of power output for three PV modules over the test period is shown in Figure 9. The figure shows that the maximum power output for PV module-1, PV module-2, and PV module3 was approximately 360,620 , and $600 \mathrm{~mW}$, respectively. The reason for less power output for PV module-1 was due to less solar irradiance received by the PV module as it had no concentrating system. The comparison of the power output for the PV modules with the $\mathrm{CPC}$ indicates that 
there was no significant difference in output power between PV module-2 and module- 3 at early hours of the day and late afternoon due to low solar irradiance incident on both PV modules. However, between 0830 and 1530 hours, it is observed that PV module-2 had higher power output than PV module-3 despite its low operating temperature. The observed difference between the two PV modules was due to the fact that PV module- 3 received relatively less amount of useful sunlight (visible light) due to high reflection of the HRW glass that was located at the exit aperture of the CPC.

\section{Conclusions}

A HRW cooling system to be used at the exit aperture of the symmetric 2D CPC was designed and evaluated, both theoretically and experimentally. Experimental result shows that a glass coated with $180 \mathrm{~nm}$ layer of ITO can maintain $\mathrm{PV}$ module temperature at $45^{\circ} \mathrm{C}-50^{\circ} \mathrm{C}$ range at solar noon. Below solar noon, the module temperature was lower than $40^{\circ} \mathrm{C}$. These values were lower than that of a similar PV module without the HRW by about $50 \%$. Based on this simple and low-cost cooling technology, the PV module can operate under concentrating system for many years without significant reduction in its initial power output. However, the use of ITO coated glass was found to reduce the visible radiation energy by about $15 \%$ which caused the decrease in power output for PV module-3. This negative effect was due to high reflection of visible light by the HRW glass that was used in the study and may be reduced by antireflection coating. In this context, the study regarding controlling the thickness and density of metal coatings, in order to decrease the reflectivity and increase the transmission, would be an interesting contribution to this field.

\section{Conflict of Interests}

The author declares that there is no conflict of interests regarding the publication of this paper.

\section{Acknowledgment}

The author wishes to thank Dr. Aggelos Zacharopoulos (University of Ulster, UK) for his simulation ray-tracing program.

\section{References}

[1] D. I. Paul, Characterisation of solar concentrating systems for photovoltaics and their impact on performance [Ph.D. thesis], Ulster University, Derry, UK, 2011.

[2] D. I. Paul, M. Smyth, A. Zacharopoulos, and J. D. Mondol, "The design, fabrication and indoor experimental characterisation of an isolated cell photovoltaic module," Solar Energy, vol. 88, pp. $1-12,2013$.

[3] E. Skoplaki and J. A. Palyvos, "On the temperature dependence of photovoltaic module electrical performance: a review of efficiency/power correlations," Solar Energy, vol. 83, no. 5, pp. 614-624, 2009.

[4] M. A. Quintana, D. L. King, T. J. McMahon, and C. R. Osterwald, "Commonly observed degradation in field-aged photovoltaic modules," in Proceedings f the Conference Record of the 29th IEEE Photovoltaic Specialists Conference, pp. 1436-1439, New Orleans, La, USA, May 2002.

[5] K. Araki, H. Uozumi, and M. Yamaguchi, "A simple passive cooling structure and its heat analysis for $500 \mathrm{x}$ concentrator PV module," in Proceedings of the Conference Record of the TwentyNinth IEEE Photovoltaic Specialists Conference, pp. 1568-1571, May 2002.

[6] A. Royne, C. J. Dey, and D. R. Mills, "Cooling of photovoltaic cells under concentrated illumination: a critical review," Solar Energy Materials and Solar Cells, vol. 86, no. 4, pp. 451-483, 2005.

[7] M. A. Rosen and R. Kumar, "Performance of a photovoltaic/ thermal solar air heater: effect of vertical fins on a double pass system," International Journal of Energy and Environmental Engineering, vol. 2, no. 4, pp. 1-12, 2011.

[8] C. M. Maghanga and M. M. Mwamburi, "Contribution of spectrally selective reflector surface to heat reduction in silicon concentrator solar cells," in Solar Power, R. D. Rugescu, Ed., chapter 13, InTech, Rijeka, Croatia, 2012.

[9] M. Rönnelid, B. Perers, B. Karlsson, and P. Krohn, "Active cooling of low-concentrating hybrid PV/thermal collectors," in Proceedings of the 8th International Biannual Conference on Solar Energy in High Latitudes (North Sun '99), Edmonton, Canada, August 1999.

[10] J. S. Coventry, "Performance of a concentrating photovoltaic/ thermal solar collector," Solar Energy, vol. 78, no. 2, pp. 211-222, 2005.

[11] Y. Zhangbo, L. Qifen, Z. Qunzhi, and P. Weiguo, “The cooling technology of solar cells under concentrated system," in Proceedings of the 6th IEEE International Power Electronics and Motion Control Conference (IPEMC '09), pp. 2193-2197, IEEE, Wuhan, China, May 2009.

[12] E. Barrera, I. González, and T. Viveros, "A new cobalt oxide electrodeposit bath for solar absorber," Solar Energy Materials and Solar Cells, vol. 51, no. 1, pp. 69-82, 1998.

[13] "Solar Heat Reflective Coatings," Cool chemistry, AkzoNobel Aerospace Coatings limited, 2009, http://www.anac.com/.

[14] K. L. Chopra and S. R. Das, Thin Film Solar Cells, Plenum Press, New York, NY, USA, 1983.

[15] A. E. J. Gonzalez and J. A. S. Urueta, "Optical transmittance and photoconductivity studies on $\mathrm{ZnO}$ :Al thin films prepared by the sol-gel technique," Solar Energy Materials and Solar Cells, vol. 52, no. 3-4, pp. 345-353, 1998.

[16] R. Ahmad-Bitar and D.-E. Arafah, "Processing effects on the structure of $\mathrm{CdTe}, \mathrm{CdS}$ and $\mathrm{SnO}_{2}$ thin films," Solar Energy Materials and Solar Cells, vol. 51, no. 1, pp. 83-93, 1998.

[17] M. M. Mwamburi and R. T. Kivaisi, "Preparation and characterisation of RF sputtering ITO films," in Proceedings of the 3rd College on Thin Film Technology, Dar es Salaam, Tanzania, JulyAugust 1994.

[18] E. Bernamar, A. Ennaoui, C. Messaoudi, M. Rami, and D. Sayah, "Structural, optical and electrical properties of indium tin oxide films prepared by pyrolysis," Solar Energy Materials and Solar Cells, vol. 56, no. 2, pp. 125-139, 1999.

[19] H. L. Hartnagel, A. L. Dawar, A. K. Jain, and C. Jagadish, Semiconducting Transparent Thin Films, Institute of Physical Publishing, Bristol, UK, 1995.

[20] J. George and C. S. Menon, "Electrical and optical properties of electron beam evaporated ITO thin films," Surface and Coatings Technology, vol. 132, no. 1, pp. 45-48, 2000. 
[21] S. Bhagwat and R. P. Howson, "Use of the magnetron-sputtering technique for the control of the properties of indium tin oxide thin films," Surface and Coatings Technology, vol. 111, no. 2-3, pp. 163-171, 1999.

[22] A. Salehi, "The effects of deposition rate and substrate temperature of ITO thin films on electrical and optical properties," Thin Solid Films, vol. 324, no. 1-2, pp. 214-218, 1998.

[23] S. H. Brewer and S. Franzen, "Optical properties of indium tin oxide and fluorine-doped tin oxide surfaces: correlation of reflectivity, skin depth, and plasmon frequency with conductivity," Journal of Alloys and Compounds, vol. 338, no. 1-2, pp. 73-79, 2002.

[24] H. N. Cui, Chapter 4, indium tin oxide films deposited by d.c. sputtering, preparation and characterization of optical multilayered coatings for smart windows applications [Doctoral Thesis], University of Minho, Braga, Portugal, 2005.

[25] S. Pati, "Thin film growth techniques: importance of thin films," International Journal of Advanced Technology in Engineering and Science, vol. 3, no. 8, pp. 163-168, 2015.

[26] J. W. Bae, J. S. Kim, and G. Y. Yeom, "Indium-tin-oxide thin film deposited by a dual ion beam assisted e-beam evaporation system," Nuclear Instruments and Methods in Physics Research $B$, vol. 178, no. 1-4, pp. 311-314, 2001.

[27] V. Craciun, D. Craciun, Z. Chen, J. Hwang, and R. K. Singh, "Room temperature growth of indium tin oxide thin films by ultraviolet-assisted pulsed laser deposition," Applied Surface Science, vol. 168, no. 1-4, pp. 118-122, 2000.

[28] M. J. Alam and D. C. Cameron, "Characterization of transparent conductive ITO thin films deposited on titanium dioxide film by a sol-gel process," Surface and Coatings Technology, vol. 142144, pp. 776-780, 2001.

[29] Y.-N. Kim, S.-M. Jeong, M.-S. Jeon, H.-G. Shin, J.-K. Song, and H.-S. Lee, "Reliability assessment of indium tin oxide thin films by accelerated degradation test," Journal of Electroceramics, vol. 17, no. 2-4, pp. 955-958, 2006.

[30] D. Mergel, M. Schenkel, M. Ghebre, and M. Sulkowski, "Structural and electrical properties of $\operatorname{In}_{2} \mathrm{O}_{3}: \mathrm{Sn}$ films prepared by radio-frequency sputtering," Thin Solid Films, vol. 392, no. 1, pp. 91-97, 2001.

[31] L.-J. Meng and M. P. dos Santos, "Properties of indium tin oxide films prepared by $\mathrm{rf}$ reactive magnetron sputtering at different substrate temperature," Thin Solid Films, vol. 322, no. 1-2, pp. 56-62, 1998.

[32] C. Nunes de Carvalho, G. Lavareda, E. Fortunato, and A. Amaral, "Properties of ITO films deposited by r.f.-PERTE on unheated polymer substrates-dependence on oxygen partial pressure," Thin Solid Films, vol. 427, no. 1-2, pp. 215-218, 2003.

[33] ITO-Coated Glass Specifications, Präzisions Glas \& Optik GmbH, Iserlohn, Germany, 2016.

[34] Anon, Electrical Characteristics of Polycrystalline Silicon, Shuang Li Electronics, Zhenjiang, China, 2014.

[35] Fluke 114, 115 and 117 True-RMS Multimeters User Manual, Fluke Corporation, Everett, Wash, USA, 2006.

[36] A. Zacharopoulos, D. I. Paul, J. D. Mondol, and M. Smyth, "Optical characterisation of a PV concentrator under cimulated and realistic solar conditions using an isolated cell PV module," in Proceedings of the Eurosun Conference, Opatija, Croatia, September 2012.

[37] C. R. Osterwald, J. Adelstein, J. A. Del Cueto et al., "Resistive loading of photovoltaic modules and arrays for long-term exposure testing," Progress in Photovoltaics, vol. 14, no. 6, pp. 567-575, 2006.
[38] F. Lasnier and T. Ang, Photovoltaic Engineering Handbook, Adam Hilger, Bristol, UK, 1990.

[39] C. R. Nave, Resistance: Temperature Coefficient, Department of Physics and Astronomy, Georgia State University, Atlanta, Ga, USA, 2005, http://hyperphysics.phy-astr.gsu.edu/hbase/electric/restmp.html.

[40] E. Coates, "Resistor parameters, 6.01 reversed version, Electronics," 2015, http://www.learnabout-electronics.org/Resistors/ resistors_00.php.

[41] M. Smyth, The design and development of a heat retaining integrated collector/storage solar water heater (ICSSWH) [Ph.D. thesis], Ulster University, Coleraine, UK, 1998.

[42] A. Rabl, P. Bendt, H. W. Gaul, and K. A. Reed, "Optical analysis and optimization of line focus solar collectors," U.S. Department of Energy, Task NREL/TR-34-92, Solar Energy Research Institute, Contract no. EG.77.C.01.4042, 1979.

[43] A. Rabl, "Optical and thermal properties of compound parabolic concentrators," Solar Energy, vol. 18, no. 6, pp. 497511, 1976.

[44] A. Zacharopoulos, Optical design modelling and experimental characterisation of line-axis concentrators for solar photovoltaic and thermal applications [Ph.D. thesis], Ulster University, Derry, UK, 2001.

[45] M. A. Green, Third Generation Photovoltaics: Advanced Solar Energy Conversion, Springer, Berlin, Germany, 2006.

[46] W. T. Welford and R. Winston, The Optics of Non-Imaging Concentrators, Academic Press, New York, NY, USA, 1978.

[47] G. Barakos, "Design, simulation and performance of reflecting parabolic solar collector," in Socrates Programme: A European Summer School; an Intensive Course on 'ICT Tools on PVSystems Engineering: Teaching \& Learning', Department of Mechanical Engineering Technological Educational Institute of Patra, Patras, Greece, 2006. 

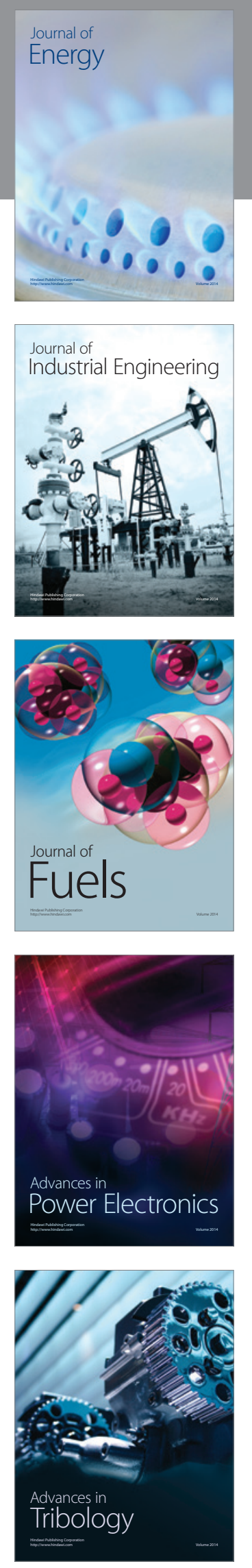
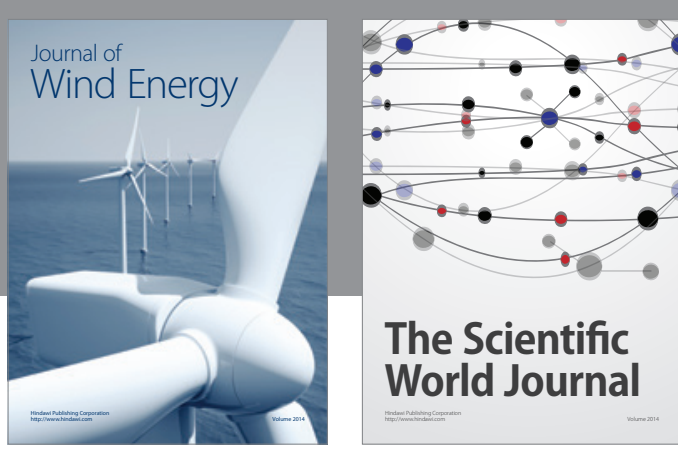

The Scientific World Journal
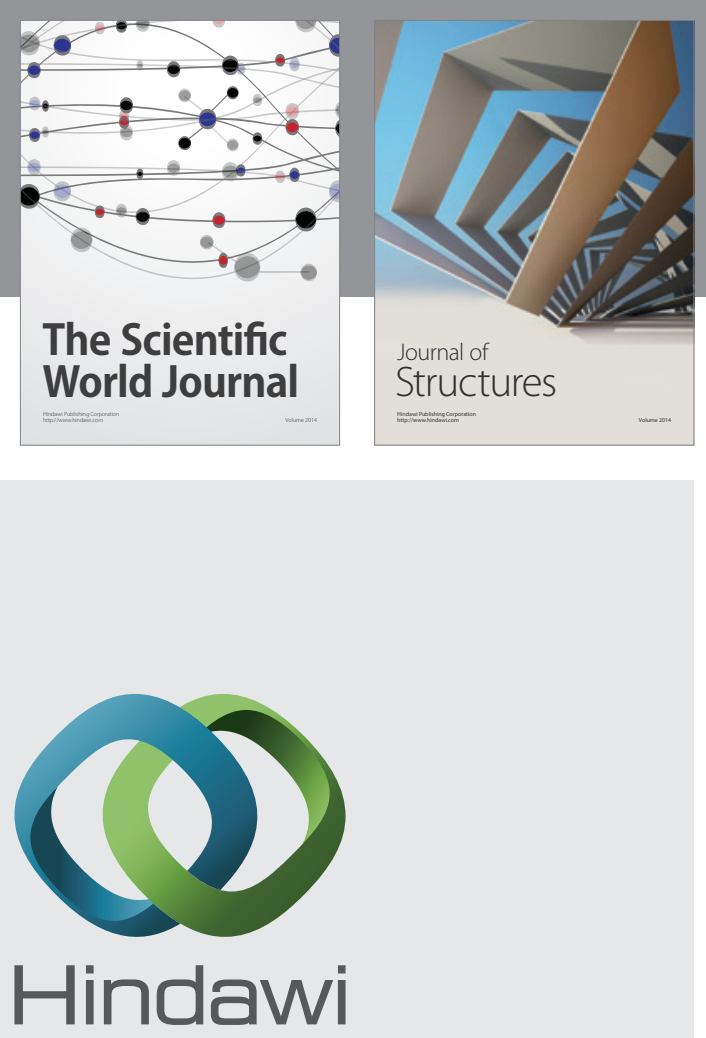

Submit your manuscripts at

http://www.hindawi.com
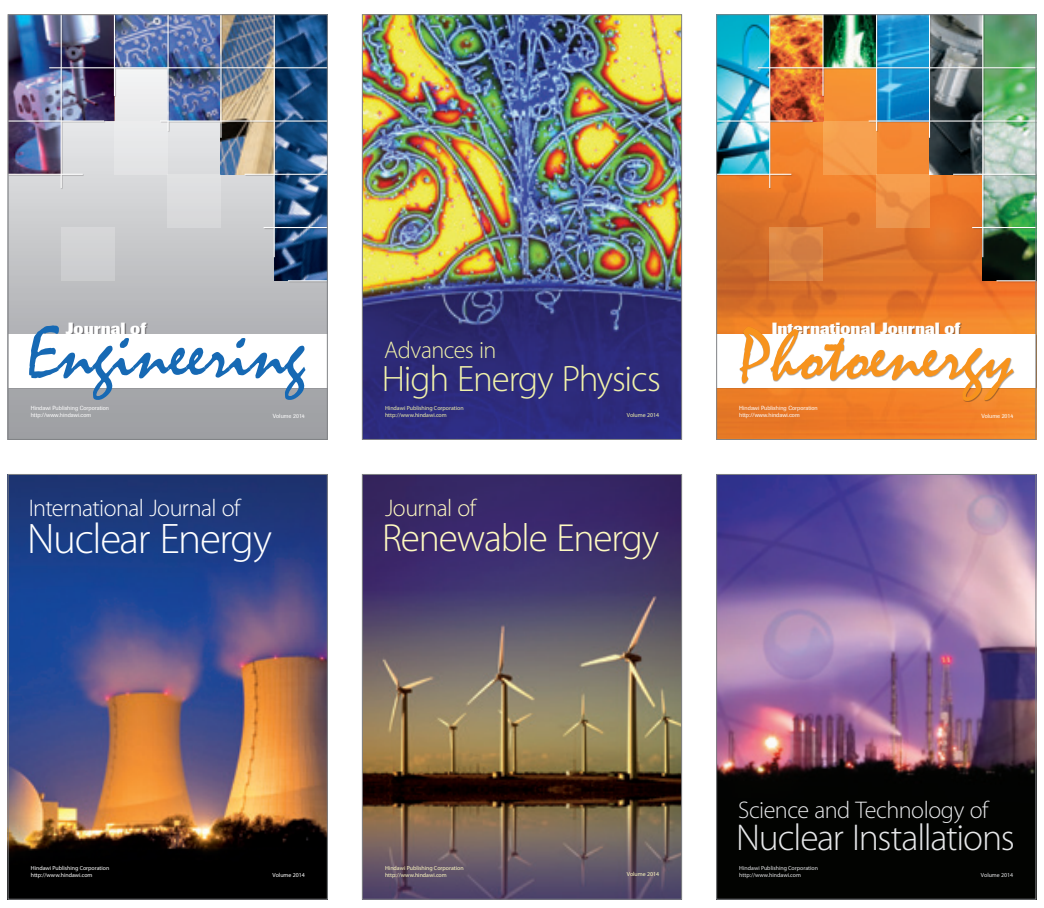
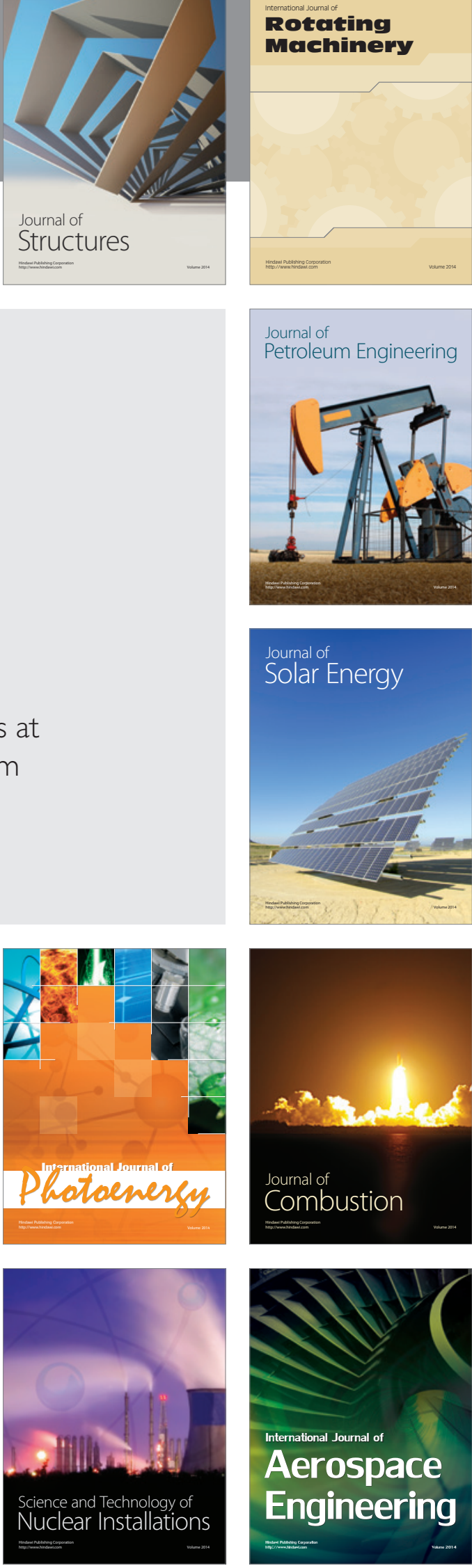